\title{
時間交通需要変動特性を考慮した交通性能照査型道路計画設計法*
}

\section{A Methodology of a Traffic-Performance-Oriented Highway Planning and Design Considering Hourly Traffic Demand Fluctuation*}

\author{
内海泰輔**，中村英樹*** \\ By Taisuke UTSUMI** and Hideki NAKAMURA***
}

\section{1. はじめに}

極めて厳しい財政制約の中，我が国では今まで以上 にコスト・パフォーマンスの高い道路を計画設計するこ とが求められている．本論文は，その道路の持てる交通 性能を十分発揮しつつもコストを抑えることのできる, 合理的な道路構造と交通運用の組合せを導入可能な，性 能照査型の道路計画設計法を示すことを目的とする.

\section{2. 道路計画設計方針の再考の必要性}

\section{(1) 設計の考え方 ${ }^{1) ~ 3) な と ゙ ~}$}

一般に構造物や製品の設計の考え方には，「性能照査 型」と「仕様型」とがある.

性能照査型とは，その設計物に求められる性能を満 足するか否かを事前に照査し設計する考え方であり，こ れに基づくことによって設計物の性能を確認することが できる. また，この設計法によれば，求められる性能さ え満足すればいかなる手法でも採用できるため, 最新の 技術や工法を比較的自由に導入することが可能であり， 様々な制約条件の中で最も適切な手法を選択することが できる. しかしその一方で，設計物の性能を的確に照査 しなければならず，これがこの考え方を適用する上で大 きな障害となる場合がある. たとえば，個々の地点の自 然条件に応じて設計条件が大きく変化する土木構造物の 性能照査には，数多くの経験が必要とされ，技術者に高 い技術力が要求される.

これに対して仕様型とは, 過去の研究や経験などに 基づき定められた仕様によって設計する考え方である. これは，設計物の性能を照査する必要がなく技術者の負 担を質・量ともに軽減でき，一定水準のものを短期間で 大量に生産する場合に適している. しかし，時代の流れ

* キーワーズ : 道路計画設計, 性能照査, 交通需要変動

**正会員 博(工) 㧣長大 西日本社会計画事業部 道路交通計画部 (大阪市西区新町2-20-6

E-mail: utsumi-tachodai.co.jp)

***正会員 工博 名古屋大学大学院 教授 工学研究科社会基盤工学専攻 (名古屋市千種区不老町C1-2(651)

E-mail: nakamura(a)genv.nagoya-u.ac.jp)
や技術水準の進歩によって求められる性能が，仕様が規 定された当時から変化したり，新たな性能指標での評価 が求められたりするようになると，これらを満足できな いものを設計する惧れがある．また，仕様が強制力のあ るルールや法令となる場合が多く，たとえ良質で経済的 な技術，工法が開発されても，これらを簡単に導入でき ないという欠点も併せ持っている.

(2) 現行の道路計画設計法とその功罪

現在，我が国の道路は，道路構造令 ${ }^{4}$ に基づき計画設 計されている.これは，自動車専用道路(以下，自専道) か㧵かと地方部/都市部により区分される種と，地形区 分, 道路種別, 計画交通量によって決まる級の組合せ (以下, 種級区分)に応じて道路横断面の仕様が定められ ているもので，いわゆる仕様型設計である.

産業や生活の基盤となる道路が絶対的に不足してい た戦後の高度成長期には，ある一定水準の道路を短期間 で大量に整備することが求められ，現行の仕様型設計は 極めて重要な役割を果たしたといえる.しかし，既にか なりの量的ストックが形成され，道路整備の目標が量の 拡充から質の向上人と替わりつつあり, 真に必要な道路 やその適切な構造とは何かが問われる現在，この仕様型 設計が必ずしも適切な計画設計法であるとはいえないの ではなかろうか。

道路には，旅行速度など道路機能に応じて求められ る性能があり，本来それを満足するように計画設計しな ければならない，しかし，現行の仕様型設計にはこのよ うな思想が十分反映されておらず，求められるべき性能 が確認されないまま道路を計画設計してしまう場合があ る。また，信号制御やリバーシブルレーンなどの交通運 用が計画設計段階では十分考慮されることがないため, 交通需要変動に応じて持てる性能が十分発揮できなかっ たり, 必要以上にコストのかかる構造になったりする場 合も多いと考えられる. これらの解決策の一つとして, 時代に応じて弾力的に仕様を変更することが考えられる. が，それにはかなりの時間を要し短期間に仕様を変更す ることは難しい，実際に，現行の仕様の基本は，1970年 以降実質的にほとんど変更されていない. 


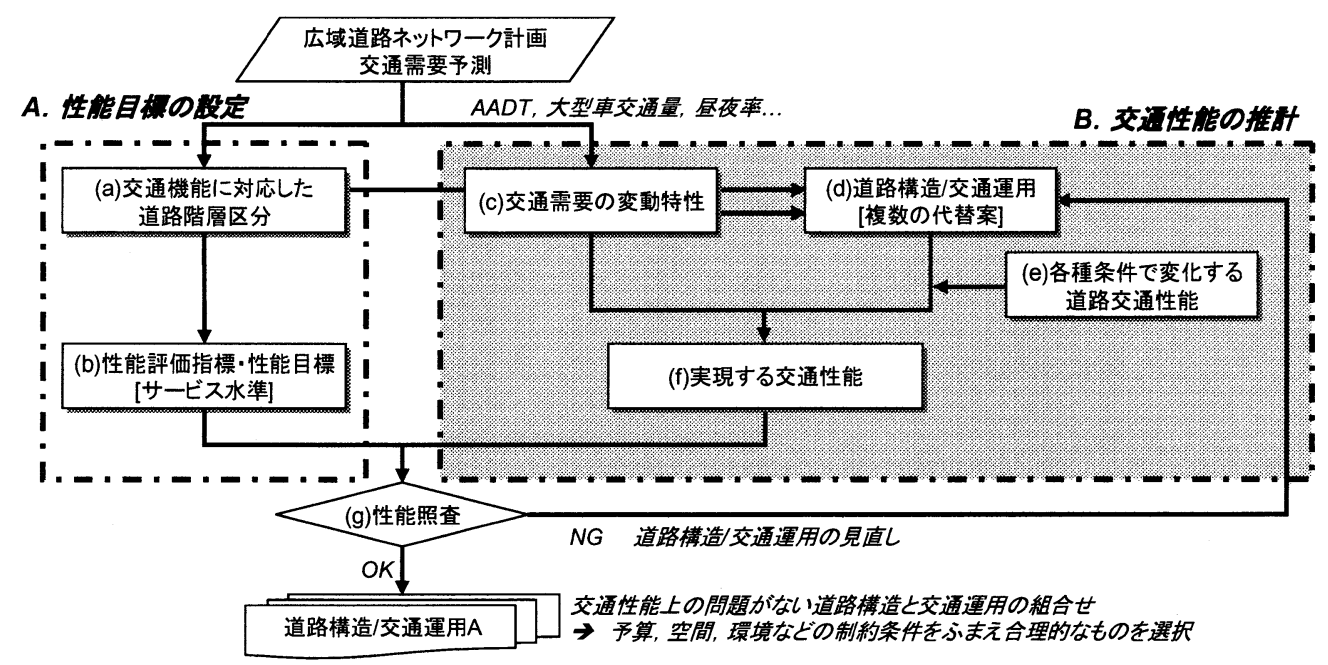

図-1 本論文における性能照査型道路計画設計法のフレームワーク

(3)「仕様型」から性能照査型」へ

道路を取り巻く環境の変化を考慮すると, 道路の計 画設計法は，現行の仕様型から，道路の機能に応じて求 められるべき性能を確認でき, また予算, 空間, 環境と いった制約条件の中で最も適切な道路構造と交通運用の 組合せが選択できる性能照査型へと転換すべきであろう。 またこの際には，後述するように，道路構造や交通運用 を検討する上で最も重要な事項の一つである交通需要の 変動特性についても適切に表現することが必要である.

本論文では，まず，時間交通需要変動を考慮して計 画設計道路の性能を推計する手法を構築する. そして, これと性能目標とを組合せることで, 計画設計道路の性 能を事前に照査する性能照查型の道路計画設計法を示す. なお，ここでは道路の性能を交通性能とし，その中でも 特に都市間道路などで重視される走行性能を対象とする.

\section{3. 性能照査型道路計画設計法のフレームワーク}

これまでに提案されたコンセプト5フフに基づき，性能 照査型道路計画設計法のフレームワークを図-1に示す.

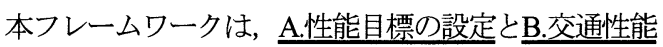
の推計の $2 つ の$ 部分で構成される. そして, これらを組 合せることで，計画設計道路の交通性能を照査し，その 道路に求められる性能を満足する道路構造と交通運用の 組合せを出力する.

まず前者では，上位の広域道路ネットワーク計画や 交通機能などの観点から, その道路に求められる(a)交 通機能に対応した道路階層区分と，それに応じた適切な (b)性能評価指標・性能目標を設定する.

一方後者では, 従来からの手順に準じた交通需要予
測などにより，計画設計道路の年平均日交通量(以下， AADT; Annual Average Daily Traffic volume)や大型車交通 量, 昼夜率といった基本的な交通条件を予測あるいは想 定し, (c)交通需要の変動特性を推計する[需要側]. また 別途, (a)道路の階層区分や(c)交通需要の変動特性など に応じて適切な(d)道路構造と交通運用の組合せを想定 する[供給側]. そして, (c)交通需要の変動特性と(d)道路 構造と交通運用を組合せ, 計画設計道路の(f)交通性能を 推計する. 但し，これには，与えられた交通需要はもと より, 車線幅員や絎断勾配, 大型車混入率, 天候といっ た様々な条件・要因によって変化する(e)道路の交通性 能(たとえば，交通量-速度曲線など)を明らかにしておく ことが必要である.

最後に, 推計された(f)交通性能を(b)性能目標により (g)照査し，道路構造と交通運用の可否を判定する. な お, 求められる性能を満足する代替案が複数存在する場 合は，予算，空間，環境といった様々な制約条件を考慮 し, 最も適切なものを選択する. その結果, その道路の 持てる交通性能が発揮できる合理的な道路構造と交通運 用の組合せを導入することが可能となる.

このような手法を採用することによって，それぞれ の道路の機能に応じて求められる性能を事前に確認する ことができる. たとえば，走行性能が求められる都市内 幹線街路では，信号交差点の連続によって旅行速度が低 下するかどうかを事前にチェックし，その対策を検討す ることができる. あるいは，狭幅員車線や路肩の走行車 線としての運用時の(e)道路交通性能がわかれば，予算 的，空間的制約などの理由から自専道のボトルネック区 間で容易に車道幅員の拡幅が行えない場合に, 部分的に 車線幅員を狭めてでも車線数を増やしたり，ピーク時に 路肩を走行車線として運用したりすることを前提に設計 
表-1 筆者ら ${ }^{12)}$ が提案する新たな道路カテゴリ分類

\begin{tabular}{|c|c|c|c|c|c|}
\hline 大分類 & 嫴 & 小分類 & 詳 & $\begin{array}{c}\text { 一般道 } \\
\text { [Highway] } \\
\end{array}$ & $\begin{array}{c}\text { 自寻道 } \\
\text { [Motorway] } \\
\end{array}$ \\
\hline \multirow{2}{*}{$\begin{array}{c}\text { 幹線 } \\
\text { [Arterial] }\end{array}$} & \multirow{2}{*}{$\begin{array}{l}\text { 大都市，主要都市間を連絡するように分布してい } \\
\text { る.AADT，大型車交通量ともに多い。また，昼 } \\
\text { 夜率が } 1.50 \text { 以上と高く，夜間の利用も多い. }\end{array}$} & 重要幹線 & $\begin{array}{l}\text { 首都圈/閏西圈などの大都 } \\
\text { 巾圈を連絡する幹線 }\end{array}$ & $\begin{array}{l}\mathrm{H} 1: \text { 重要幹線 } \\
(88)\end{array}$ & $\begin{array}{l}\text { M1：重要幹線 } \\
(242)\end{array}$ \\
\hline & & 幹線 & $\begin{array}{l}\text { 大都市圈と主要都市など } \\
\text { を連絡する地方部の幹線 } \\
\end{array}$ & - & $\begin{array}{c}\text { M2: 幹線 } \\
(265)\end{array}$ \\
\hline \multirow{3}{*}{$\begin{array}{c}\text { 都市内/周辺 } \\
\text { [Urban] }\end{array}$} & \multirow{3}{*}{ 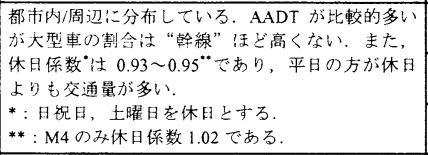 } & 大都市 & $\begin{array}{l}\text { 首都圈，関西圈，中京圈 } \\
\text { の三大都市圈 }\end{array}$ & \multirow{2}{*}{$\begin{array}{c}\mathrm{H} 2 \text { : 大都市内/周辺道路 } \\
(266)\end{array}$} & $\begin{array}{c}\text { M3: 大都市周辺路線 } \\
(262)\end{array}$ \\
\hline & & 主要都市 & $\begin{array}{l}\text { 札㹸や仙台, 広島, 福馗 } \\
\text { など地方県の主要都市 }\end{array}$ & & $\begin{aligned} \text { M4 : 主要都市周辺路線 } \\
(610)\end{aligned}$ \\
\hline & & 地方都市 & $\begin{array}{l}\text { 上記以外の地方部の中小 } \\
\text { 都市 }\end{array}$ & $\begin{array}{c}H 3 \text { : 地方都市内/周辺道路 } \\
(252)\end{array}$ & 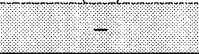 \\
\hline $\begin{array}{c}\text { 地域生活圈 } \\
\text { [Local] }\end{array}$ & $\begin{array}{l}\text { 地方部に幅広く分布している. “幹線”, “都市内 } \\
\text { 周辺”に比べて AADT, 大型車交通量ともに少な } \\
\text { い. 平日は地域の生活道路として, 休日は観光道 } \\
\text { 路としての変動特性みられる. }\end{array}$ & & & $\begin{array}{l}\text { H4：地域生活圈道路 } \\
\text { (276) }\end{array}$ & $\begin{array}{c}\text { M5：地域生活圈路線 } \\
\text { (475) }\end{array}$ \\
\hline $\begin{array}{c}\text { 観光 } \\
\text { [Sightseeing] }\end{array}$ & 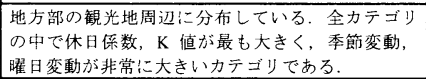 & & $=$ & $\begin{array}{l}\text { H5：钼光道路 } \\
(100)\end{array}$ & $\begin{array}{l}\text { M6 : 钼光路線 } \\
\text { (205) }\end{array}$ \\
\hline
\end{tabular}

※一般道延べ 892 地点自専道延べ 2,059 地点の車両感知器データを用いてクラスター分析により分類した結果（ )内の值は，そのとき各力テゴリに分類された地点数.

でき，所要の交通性能を確保することが可能となる.

(a)交通機能に対応した道路階層区分については, 最 近の研究8),9)で既に提案されたものを前提とする. また, (b)性能評価指標・性能目標は, 上位の広域道路ネット ワーク計画や交通機能などの観点から設定されるべきも ので，一般に道路を計画設計する際の与件である. この 決定方法も重要な研究テーマの1つであり, 今後研究し ていく必要がある. 本論文では，特にBの部分に着目し 計画設計道路の交通性能を推計する手法を構筑する.

\section{4. 年間を通じた時間交通需要の変動特性 $[$ 図-1 (c)]}

道路の計画設計に際しては, その道路の交通需要の 変動特性を的確に把握することが重要である.

現行の道路計画設計法では, 30番目時間交通量を設 計時間交通量とし交通需要の変動特性を代表させている. この30番目時間交通量は，一般に地域特性により異なる

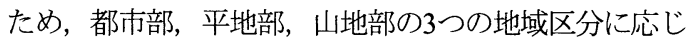
て，30番目時間交通量のAADTに対する百分率であるK 值の標準值が $9 \%, 12 \%, 14 \%$ と定められている.

しかし，この考え方には次のような問題がある.

\section{問題 1 ; 不十分な路線特性，地域特性の考慮}

観光系道路のように交通需要の変動が大きな路線で は, 現行の道路計画設計法で用いられているK值の標準 值と実態とが大きく乘離している場合がある ${ }^{10,11)}$. 現行 の3つの地域区分のみでは, 多様な交通需要の変動パタ ーンを的確に反映することは難しい.

\section{問題2 ; 単一の時間帯を設計対象とする問題}

30 番目時間交通量のような特定の時間交通量で交通 需要の変動特性を代表させ, 道路の交通性能を評価する ことは, 残り年間8,759時間の交通性能を適切に評価し ているとは言い難い.

\section{問題3; 時間交通量(需要)の時系列的因果関係の問題}

直前の時間帯に溜滞が存在する場合, たとえその時

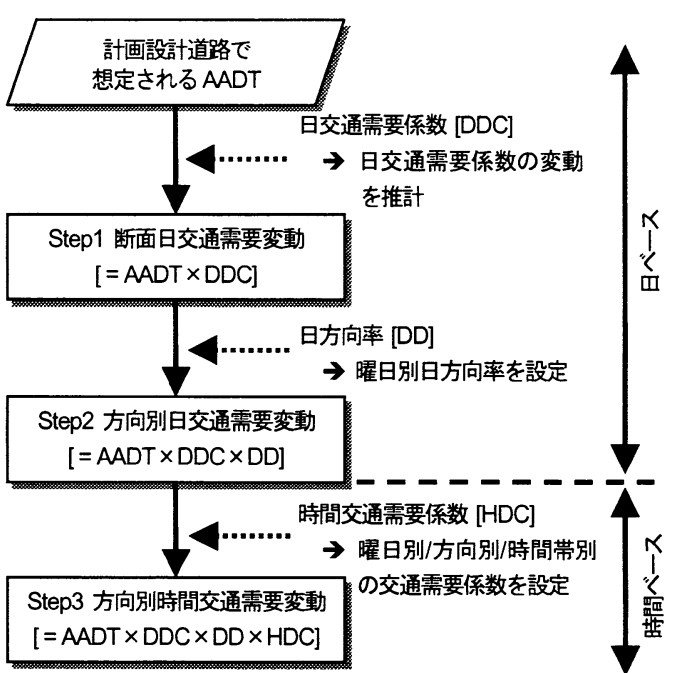

図-2 方向別時間交通需要変動の推計フロー ${ }^{13)}$

間帯の交通需要が他の時間帯と同一であっても，実際の 交通状況は大きく異なる. しかし，現行の道路計画設計 法では, 時間交通量を大きい順に並べ替えて評価するた め, このような交通需要の時系列的な因果関係について は考慮できない。

上述の問題1に対して，筆者ら ${ }^{12}$ は, AADTや大型車 交通量, 昼夜率といった計画設計段階で比較的予測ある いは想定しやすい交通指標を用いることによって, 路線 や地域の特性を考慮した, 表-1のような道路カテゴリ分 類を提案している.

また, 問題2,3については, 図-2に示すフローに基づ き都市間道路の年間 8,760 時間の交通需要を時系列的に 推計する手法を構築し, 既往研究 ${ }^{22}$ で提案した道路カテ ゴリごとに年間を通じた平均的な時間交通需要変動パタ ーンを推計している ${ }^{13)}$. 但し, このときの交通需要は, 道路上に顕在化し車両感知器などで観測される交通量で あり，道路整備などによって新たに顕在化する可能性が ある潜在的な交通需要ではないことに注意が必要である. また, 既往研究 ${ }^{13)}$ では, 全カテゴリ一律に平日のピー 
ク時間帯を基準に重方向を設定しているが，ここでは各 カテゴリの矅日変動特性に着目し, 日交通量が休日より も平日の方が多いカテゴリ $(\mathrm{H} 1, \mathrm{H} 2, \mathrm{H} 3, \mathrm{M} 3)$ は平日」の ピーク時間帯を, 休日の方が多いカテゴリ $(\mathrm{H} 4, \mathrm{H} 5, \mathrm{M} 1$, M2, M4, M5, M6)は「休日」のピーク時間帯を, それぞれ 基準にし重方向を設定する.

なお，本論文では紙面の制約上，5章以降は東名高速 や名神高速など都市間自専道の中でも特に重交通路線が 属する道路カテゴリM1を対象とした結果のみを示す.

\section{5. 道路構造と交通運用 [図-1 (d)]}

我が国の道路は，方向別交通量に特に差がある場合 に限り奇数の車線数で運用されることもあるが，少なく とも設計段階においては原則として2車線，4車線，6車 線といった偶数の両方向同一車線数で検討が行われる.

また, 車道/車線や路肩といった横断面構成要素の設計 值は，予め基本值が定められており，ほぼ統一的な道路 構造となっている.

一方, ドイツやスウェーデンなどでは, 通常の偶数 車線だけでなく, リバーシブルレーンや2+1車線道路と いった奇数車線数での運用も少なくない. また, 工事の 際には車線幅員を狭めて車線数を確保したり, ピーク時 に十分な性能が達成できない場合には路肩を走行車線と

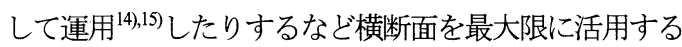
特殊な道路構造と交通運用が採り入れられている. 今後 の道路の計画設計は，欧米諸国にみられるような合理的 な道路構造と交通運用の組合せを導入すべきと考える.

本論文では, 交通量が多く, 方向別交通量の差が小 さい重交通路線(M1)の道路構造と交通運用として, 4 車 線, 並びに6車線といった通常の多車線の道路構造と, その中間的な道路構造と位置づけられ既に諸外国で導入 実績のある，4車線であるがピーク時に性能が達成でき ないときには動的に路肩を走行車線とする運用(以下， 4 車線十動的路肩運用)の3つを採り上げる.

\section{6. 各種条件で変化する道路交通性能 [図-1(e)]}

交通条件や道路条件などに応じて道路の走行性能は 変化する.ここでは，走行性能の評価指標を旅行速度と し, 各種条件に応じて変化する旅行速度を交通量との関 係(以下， $q$-性能曲線)により設定する. なお, 都市内街 路と異なり, 都市間道路は信号交差点が少なく, 沿道か らの出入りもほとんどない. このため, 非啮滞状態では 対象区間の地点速度と旅行速度の間に大きな差はないも のと考えられる.

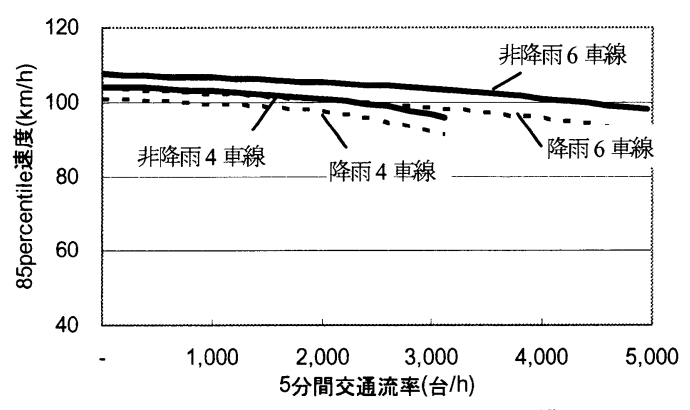

図-3 多車線自専道 $q-v$ 性能曲線 ${ }^{16)}$ [大型車混入率 : $0 \%$, 降水量 : $1 \mathrm{~mm} / \mathrm{h}$ ]

図-3は, Hong and Oguchi ${ }^{16}$ が提案している我が国の多 車線自専道の一般的な断面における $q$-v性能曲線である. ここで速度りは地点の85percentile速度(以下, 速度)である. Hong and Oguchi は, 東名高速や東北道など我が国の主 要な多車線高速道路に設置されている車両感知器データ を用いて, 大型車混入率や降水量に応じた $q$-v性能曲線 について分析し, 大型車混入率の増加による速度の低下 量は交通量の増加に伴い大きくなること, 一方, 降水量 の増加による速度の低下量は交通量とあまり関係なくほ ぼ一定であること, などを明らかにしている. そして, 車線別 $q-v$ 性能曲線(降水量別/大型車混入率別), 車種別 車線選択確率をそれぞれ定式化している. これら分析結 果を併せることで図-3のように断面 $q$-v性能曲線が設定 される. 但し, このq-v性能曲線には, 道路の車線幅員 や線形など道路条件に関する要因の影響が考慮されてい ないことに注意が必要である.

本論文では，この $q$-v性能曲線を4車線, 6車線自専道 の交通性能とする. 4車線+動的路肩運用は, 我が国で の導入実績がなく $q$-v性能曲線の分析結果が存在しない ため,ここでは6車線の場合と同等の道路交通性能を有 するものと仮定する. 将来, 4 車線+動的路肩運用の $q-v$ 性能曲線が得られれば，それを用いることが望ましいこ とは言うまでもない.

\section{7. 計画設計道路で実現する交通性能の推計 [図-1 (f)]}

4〜6章で述べた各要素を組合せ, 計画設計道路の交 通性能を推計する手法(以下, 推計手法)を構築する.

\section{(1) 各種条件の設定}

時間交通需要(4章)と $q$-v性能曲線(6章)との関係より, 各時間帯の平均速度を推計するが, 交通需要が交通容量 を超過する場合には，渋滞の影響を考慮しなければなら ない. ここでは交通容量を次のように設定し, 渋滞長を 推定して, 渋滞流内の交通状況を想定する.

a) 交通容量の設定 
表-2 多車線自専道のボトルネック交通容量の設定

\begin{tabular}{|c|c|c|c|c|c|c|}
\hline 車線数 & $\begin{array}{c}\text { 基本交通容量 : } C_{B} \\
\text { [pauh] }\end{array}$ & 平休 & BN補正係数: $\alpha$ & $\begin{array}{c}\text { 啮滞前交通容量 : BDF } \\
\left(=\alpha \times C_{B}\right) \quad[\mathrm{pauh}]\end{array}$ & 別け交通量比： $\beta$ & $\begin{array}{c}\text { 啮滞発生後別1十交通量 : QDF } \\
(=\beta \times B D F) \quad[\mathrm{pa} / \mathrm{h}]\end{array}$ \\
\hline \multirow{2}{*}{ 4車線 } & \multirow{2}{*}{$4,400^{*}$} & 平日 & $0.85^{\star}$ & 3,740 & \multirow{4}{*}{$0.85^{* *}$} & 3,180 \\
\hline & & 休日 & $0.75^{\star}$ & 3,300 & & 2,800 \\
\hline \multirow{2}{*}{ 6車線 } & \multirow{2}{*}{$6,600^{*}$} & 平日 & $0.90^{*}$ & 5,940 & & 5,050 \\
\hline & & 休日 & $0.85^{\star}$ & 5,610 & & 4,770 \\
\hline
\end{tabular}

*岡村 ・ 泉 ${ }^{(8)}$ の提案値,

**岡村ら ${ }^{191}$ の分析結果から得られた值をもとに独自に算出した值,

参考 : 東名高速・名神高速などが該当する 1 種 1 級 1 種 2 級平地部の設計交通容量は 1 車線あたり 1,660 台 $\mathrm{h}$ とされている ${ }^{20}+$

道路上で啮滞が発生するか否かは，到着交通需要と ボトルネック(以下，BN)の交通容量によって決まる. このため, 道路は単路部ベースではなく，あくまでも BNベースで計画設計しなければならないの.

一般に, 自専道の主なBNは分合流部のほかサグやト ンネルであるといわれている. 越ら ${ }^{177}$ は, 高速道路のサ グ，トンネルの渋滞現象を分析し，交通容量には渋滞前

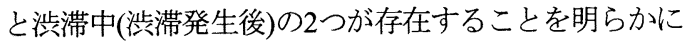
している.ここでは, BN交通容量を渋滞前交通容量(以 下, BDF; BreakDown Flow) と啮滞発生後別け交通量(以 下, QDF; Queue Discharge Flow)に分けて設定する.

本論文で設定する多車線自専道のBDF とQDFを表-2に 示す. 岡村・ 泉 ${ }^{18)}$ は, (1)当該地点(車両感知器)を含むイ ンター間で交通集中渋滞が発生していないこと, (2) $q-v$ 図がほぼ完成していること，(3)実現最大交通量がおおむ ね25年以上にわたって安定していること，の3つの条件に 合致する高速道路区間の車両感知器を抽出し, その実現 最大実 1 時間交通量により多車線高速道路一方向あたり の基本交通容量 $\left(C_{B}\right)$ を 4 車線で4,400pcu/h，6車線で 6,600 pcu/hとすることを提案している. さらに, 渋滞発 生確率 0.05 のきの渋滞発生時交通量を可能交通容量 $\left(C_{C}\right)$ と定義し, 基本交通容量 $\left(C_{B}\right)$ に対する可能交通容量 $\left(C_{C}\right)$ の比(以下, $\mathrm{BN}$ 補正係数 $\left(\alpha=C_{C} d C_{B}\right)$ ) 車線数別, 平 休別に設定している. また，岡村ら ${ }^{19}$ は，車線数別，平 休別, 渋滞要因別のBDFとQDFについて分析している. この結果から得られたBDFとQDFを用いて筆者らが独 自にBDFに対するQDFの比(以下，別け交通量比( $(\beta))$ を求 めたところ, 車線数や平休の別に依らず $0.83 \sim 0.89$ 程度 であった.ここではこれを参考に別け交通量比 $(\beta)$ を一 律に0.85とする. 本論文で設定したBDFとQDFは表-2の とおりである. なお，4車線+動的路肩運用の交通容量 の分析は行われておらず, $q$-v性能曲線の設定と同様に, 6車線のそれと同等と仮定する.

\section{b) 渋滞長の推定}

到着交通需要がBN交通容量を超過すると, BNを先頭 にした泾滞が発生し，渋滞列が上流に延伸する．この結 果, 渋滞発生後に到着する交通流は, BNよりも上流の 地点から渋滞に巻き込まれることとなる，すなわち，渋 滞長 $x$ を算出する場合には，BNには到着していないもの

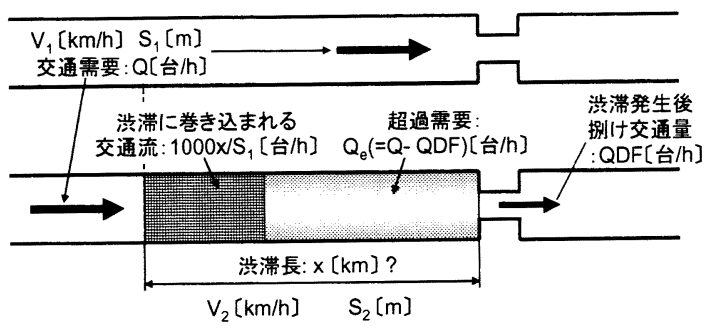

図-4 渋滞長と渋滞流に巻き込まれる交通流

の啮滞に巻き込まれる車両についても考慮しなければな らない(図-4).ここでは, 超過需要が発生した際の次の 時刻の渋滞長 $x$ を次式により適宜求める.

$$
\begin{aligned}
& \left(Q_{e}+1000 x / S_{1}\right) \times S_{2}=1000 x \quad \cdots \\
& x=\frac{Q_{e} S_{2}}{1000\left(1-\frac{S_{2}}{S_{1}}\right)}
\end{aligned}
$$

ここに, $x:$ 渋滞長 $[\mathrm{km}], Q D F: \mathrm{BN}$ の㵪滞発生後捌け交通量 [台/h], $Q:$ 到着する交通需要 $[$ 台 $/ \mathrm{h}], Q_{e}:$ 超過需要 $(=Q-Q D F)[$ 台 $/ \mathrm{h}], V_{1}:$ 非渋滞時の車両の平均速度 $[\mathrm{km} / \mathrm{h}], V_{2}$ : 橴滞流内の車両の平均速度 $[\mathrm{km} / \mathrm{h}], S_{l}$ : 非 渋滞時の平均車頭距離 $[\mathrm{m}], S_{2}$ : 跡滞流内の平均車頭 距離[m], である.

非渋滞時の車両の平均速度 $V_{1}$ はその時刻に到着する交 通需要 $Q$ と $q$-v性能曲線との関係から求め, 平均車頭距離 $S_{l}$ は交通需要 $Q$ と平均速度 $V_{l}$ より算出する $\left(S_{l}=V_{l} / Q\right)$. ま た，BNのBDFよりも大きな交通需要 $Q か ゙$ 到着する場合 は啮滞と判定し, 自専道(高速道路)の自然啮滞時の交通 密度 $k$ にり, 渋滞流内の平均速度 $V_{2}(=q / k)$, および平均 車頭距離 $S_{2}(=1 / k)$ を求める. このとき交通量 $q$ は $\mathrm{BN} の$ $\mathrm{QDF}$ とし，交通密度 $k$ は80台 $/ \mathrm{km} /$ 車線 $^{21}$ とする. このた め, 輆流内の車両の平均速度 $V_{2}$ はほぼ一定となること に注意が必要である.

\section{c) 降水量の与え方}

交通需要やBN交通容量, $q$-v性能曲線は, 降水量の影 響を受けることが既往研究(13)1622)などによって明らかにさ れている.ここでは, 降水量の影響も考慮し計画設計道 路の交通性能を推計する.

我が国では, 降水量の季節変動が大きいため, これ を考慮した時間降水量の設定が必要である. また, 前の 


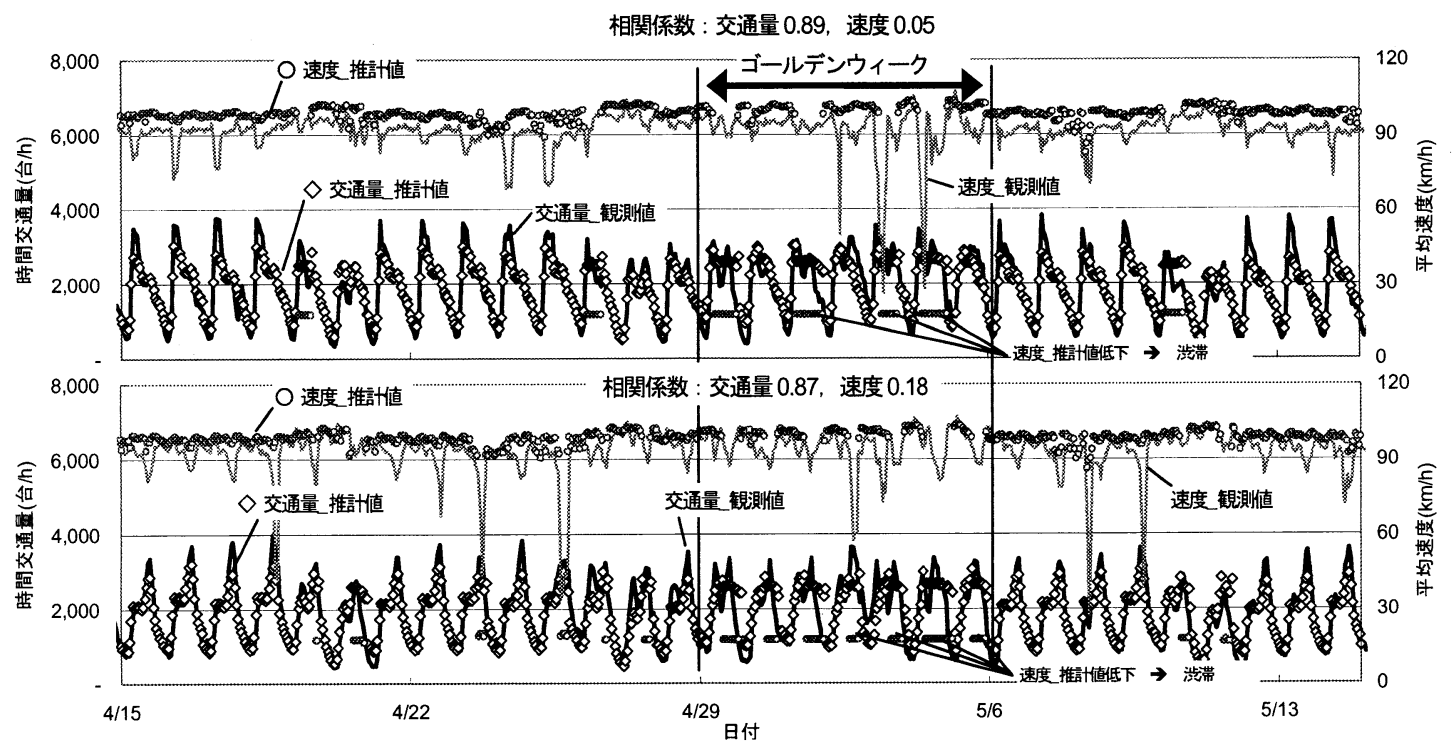

図-5 時間交通量と速度の観覞値と推計値 [上段 : 上り方向，下段 : 下り方向]

時間帯に雨が降っているか否かにより当該時間帯の降水 確率が変化するため, 対象時刻の 1 時間前の降水状況も 考慮しなければならない.ここでは, 全国のAMeDAS データを用いて確率的に降雨を発生させる，まず，時間 降水量を $0 \mathrm{~mm} / \mathrm{h}, 1 \mathrm{~mm} / \mathrm{h}, \cdots, 6 \mathrm{~mm} / \mathrm{h}$ 以上, の7つの力 テゴリに分類する．そして，月別，1時間前の時間降水 量別にサンプルを集計し，当該時間帯の降水確率を設定 する. なお，ここでは全国の平均的な值を用いるが，仮 にこれを地域別に作成すれば, 地域の気象特性も考慮し て交通性能を推計することが可能となる.

\section{（2）推計精度の検証}

a) 交通量と地点速度

東名高速の東名三好IC-名古屋IC間に設置されている 車両感知器で観測された交通量, 地点速度データにより, 本推計手法による交通性能の推計精度を検証する．なお， 本検証区間は4車線であり，検証には2003年の1年分のデ 一夕を用いる.

まず，道路カテゴリ $\mathrm{M} 1$ の年間を通じた平均的な時間 交通需要変動パターンと検証区間の2003年のAADTから， 年間の時間交通需要変動を推計する. そして, これとq性能曲線とを組合せ, 年間を通じた各時間帯の平均速 度を求める，このとき，BN交通容量は(1)で設定した值 とするが，降水量は実際に観測された值を用いる. 図-5 は，交通量と速度の観測値と推計值の一部(約1ヶ月分) を示したものである.

交通量は, 両方向とも相関係数が 0.80 以上あり, 全体 的に推計精度が良好といえる. しかし，ゴールデンウィ 一ク(4/29-5/6)のような大型連休期間は, 渋滞が観測され ていないにも関わらず，渋滞が推計されるケースがいく
つかみられる。これは，実際のBN交通容量が個々の地 点の構造条件に応じて変化し，またその值は一定ではな く変動するにも関わらず(19,23,24)など，ここでは全地点で一 律かっ一定值として扱っているためである. しかし，現 状では計画設計道路のBN交通容量やその変動特性を推 定することは難しく，ここで設定したような一般的な值 を用いるしか適当な方法がない. 今後, これらの分析が 進み，計画設計道路のBN交通容量が推定できれば，交 通量の推計精度が向上すると考えられる.

一方, 速度は, 相関係数が 0.20 にも満たず, 推計精度 が良いとはいえない.この主な原因として次のようなこ とが考えられる.

i) 先述したようにBN交通容量の設定方法に問題がある.

ii) 渋滞流内の平均速度 $V_{2}$ をQDF と交通密度 $k$ より推計 しているが，両值ともに一定值としているため，渋 滞流内の速度 $V_{2}$ も一定となる. この結果, 渋滞流内の 速度の観測值と推計值の乘離が大きくなる.

iii)ここで用いている $q$-v性能曲線には, 道路の車線幅員 や線形など道路条件の影響が考慮されていない。つ まり，検証区間固有の特性が推計されていない，

以上のように, 速度の推計精度を向上させるために は, BN交通容量をはじめ渋滞流内の平均速度や $q-v$ 性能 曲線の改良が必要である.

\section{b) 性能目標達成率}

道路カテゴリM1の4車線道路のAADT と性能目標達成 率の関係を図-6に示す。ここで性能目標達成率とは, 年 間8,760時間に対する性能目標達成時間の百分率のこと で, 両方向の平均値である. なお，このときの性能目標 は速度 $80 \mathrm{~km} / \mathrm{h}$ 以上としている. また, 観測値は, 筆者 らが既往研究 ${ }^{22)}$ で道路カテゴリ分類を提案したときに用 


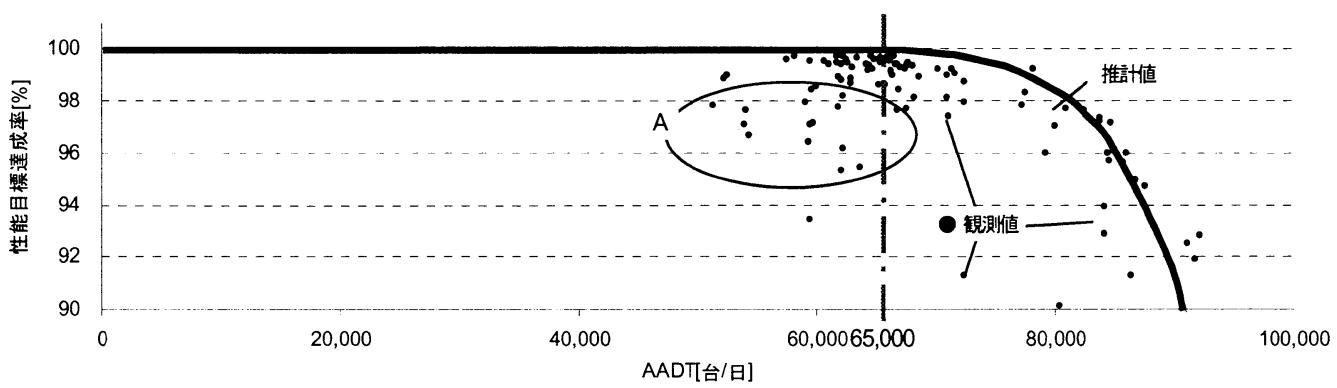

図-6 道路カテゴリ M1 の AADT と性能目標達成率の関係 [性能目標 $80 \mathrm{~km} / \mathrm{h} ， 4$ 車線]

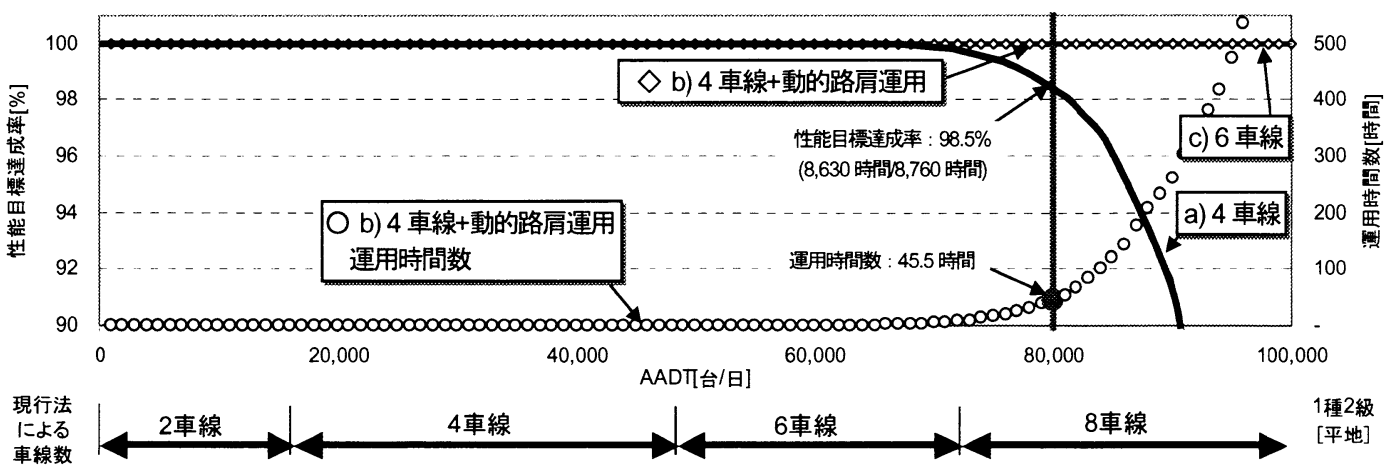

図-7 道路カテゴリ M1 の道路構造/交通運用別の AADT と性能目標達成率の推計結果[性能目標 $80 \mathrm{~km} / \mathrm{h}]$

いた車両感知器のデータであり, 道路カテゴリM1の4車 線道路の観測地点は，延べ114地点であった.

本推計手法により, AADTと性能目標達成率との関係 を推計すると, $\mathrm{AADT}=65,000$ 台/日程度までは速度 $80 \mathrm{~km} / \mathrm{h}$ 以上の性能目標を達成できることとなる. しか し，AADTがそれ以上大きくなると性能目標達成率は 徐々に低下し始め, AADT=80,000台/日を超えると急激 に低下する.

次に，観測值をみると， AADT=65,000台/日前後まで は性能目標達成率が98〜100\%であり，それ以上大きく なると推計結果と同様に性能目標達成率が低下し始める. AADT $<65,000$ 台/日で性能目標達成率 $<98 \%$ の地点を確認 したところ，その約9割が本論文で設定した4車線の $\mathrm{QDF}(2,800$ 台/h/2車線)よりもかなり小さい2,000台/ $/ \mathrm{h} / 2$ 車 線未満であるにも関わらず，速度 $80 \mathrm{~km} / \mathrm{h}$ 以上という性 能目標が達成できていなかった，このことから，これら 地点で性能目標が達成できない主な原因は, 交通集中に よるものではなく, 事故や工事, 気象(降雪, 濃霧など) などによるものと推測される．実際，図-6のAのプロッ 卜は，冬季に積雪が多い名神高速の大垣IC〜八日市IC間 のものであり，性能標が详成できない時間帯の多くが 12〜2月であった. これより, 事故や工事, 気象などの 影響さえなければ, 推計值同様にAADT=65,000台/日程 度までは速度 $80 \mathrm{~km} / \mathrm{h}$ 以上という性能目標を達成できる と考えられる。

以上のように速度の推計には改善の余地があり, 精
度の向上が求められるものの, 性能目標達成率をみると, 実際の道路で実現する交通性能の傾向を良好に推計でき ていることがわかる。 これは，性能目標達成率という指 標で評価することで, 性能目標付近の速度のみが精度検 証の対象となり，それ以外のたとえば渋滞時の速度など については一律に性能目標末達成として扱われるためで ある.このように本推計手法の出力結果は十分注意して の取り扱う必要がある.

\section{8. 横断面設計ケーススタディ}

本論文で構築した計画設計道路の交通性能の推計手法 を用いて，性能照査型の考え方で道路の横断面を計画設 計した場合のケーススタディを行う．そして，現行の仕 様型道路計画設計法と比較する。ここでは, AADT= 80,000 台/日の都市間自専道の重交通路線(道路カテゴリ M1)を対象とする.

\section{(1) 仕様型道路計画設計法(現行法)}

2章で述べたように，現行の仕様型道路計画設計法で は, 道路の種類と地形区分, 道路種別, 計画交通量によ って種級区分が設定され，それにより道路の横断面構成， 車線数がほぼ自動的に決定される.

ここで対象とする道路カテゴリ $\mathrm{M} 1$ の道路は，そのほ とんどが現行の種級区分の1種2級平地部に該当する。こ 
の種級区分では1車線あたりの設計基準交通量が12,000 台/日とされており4, AADTに応じて車線数を決定する と図-7の下部のようにAADT<48,000台/日で4車線, $\mathrm{AADT}<72,000$ 台/日で6車線となる。 これに基づくと, $\mathrm{AADT}=80,000$ 台/日の道路は8車線となる.

\section{(2) 性能照査型道路計画設計法}

道路カテゴリM1の道路は, 我が国でも最も走行性能 が重視される都市間自専道である. このため, 現行の道 路計画設計の思想の前提となっている交通集中による渋 滞発生が年間30時間未満という条件はもとより, 速度○ $\mathrm{O} \mathrm{km} / \mathrm{h}$ 以上といった走行性能を基準に性能目標を設定 すべきであろう。ここでは, 仮に性能目標を速度 $80 \mathrm{~km} / \mathrm{h}$ 以上とする. また, 今回対象とする道路構造と 交通運用は5章のとおりとするが，リバーシブルレーン や狭幅員車線なども，これらの交通運用下での道路交通 性能が明らかならば, 本推計手法によって交通性能を推 計することもできる.

道路カテゴリM1の道路を，a)4車線，b)4車線+動的路 肩運用，c)6車線で計画設計した場合のAADT と性能目 標達成率との関係を図-7に示す。これをみると， $\mathrm{AADT}=80,000$ 台/日の道路をa)4車線で計画設計すると， 年間 130 時間程度( $=8,760$ 時間 $-8,630$ 時間) 性能目標が達 成できない時間が出現することとなる，一方，b)4車線十 動的路肩運用で計画設計すると, 年間45時間程度路肩を 走行車線として運用するだけで，上述の性能目標末達成 時間を解消できる. これは，路肩を運用することで, 渋 滞そのものの発生を抑制できるだけでなく, 交通需要が BN交通容量よりも小さいにも関わらず前の時間帯の待 ち行列の影響で派生的に生じる巻き込まれ渋滞も防げる ためである. このような効果を考慮できるのは, 交通需 要の変動を時系列的に推計しているためである. そして, c)6車線で計画設計すると，特別な交通運用を行わなく とも年間全時間で性能目標を達成することができる. こ のとき，予算，空間などに制約がないならばC)6車線で 計画設計すれば良い，しかし，制約がある場合は，年間 45時間程度路肩が機能しないことを受容しb)4車線+動的 路肩運用で計画設計することも一つの選択肢といえよう.

\section{(3)「仕様型」と「性能照査型」の比較}

$\mathrm{AADT}=100,000$ 台/日以上の交通需要がある東名高速の 東京IC-厚木IC間や名神高速の京都南IC-吹田JCT間は, 現在6車線で運用されている25).この例からもわかるよ うに, 道路カテゴリM1でAADT=80,000台/日の道路は, 6車線あれば少なくとも必要最低限の走行性能は確保さ れることが実証されている．しかし，現行法をそのまま 適用すると8車線となり, 利用者の快適性は向上するも のの決して経済的な道路が計画設計されるとは言えない.
一方, 本論文で構築した交通性能の推計手法を用い て性能照査型の道路計画設計を行うと, a)4車線, b)4車 線+動的路肩運用，c)6車線, それぞれの交通性能を照査 し，また予算をはじめとした様々な制約条件を考慮した 上で，その道路の持てる交通性能が発揮できる合理的な 道路構造と交通運用の組合せを選択することが可能とな る. この結果, コスト・パフォーマンスの高い道路を計 画設計できることになる.

\section{9. おわりに}

\section{(1) まとめ}

本論文では, 時間交通需要変動の時系列的な因果関 係も考慮し, 計画設計道路の時間帯別の交通性能を推計 する手法を構築した. 本推計手法では, 速度の推計に改 善の余地が残されているものの, 性能目標達成率につい ては良好に推計することができる. 今後, 交通需要の変 動特性や道路交通性能( $($ - v性能曲線など) に関するデータ の収集・分析を進め, 本推計手法の信頼性を高めること により，実務への適用・展開も可能となると考える. ま た, 道路交通性能さえ明らかならば, リバーシブルレー ンや狭幅員車線などの様々な道路構造と交通運用の交通 性能についても推計できる.このように本推計手法は, 時間交通需要変動や道路交通性能を適切に置き換えるこ とで, 最新の知見に基づき道路の交通性能を推計できる, 汎用性の高い手法であるといえる. そして, この推計手 法を用いて, 都市間自専道の中でも特に重交通路線 (M1)の交通性能を推計した. その結果, 現行の方法で 計画設計される道路はオーバースペックとなり必ずしも 経済的でない場合もあることを示した.

さらに, 上記の計画設計道路の交通性能の推計手法 を用いた，性能照査型の道路計画設計法を示した. これ により, その道路の機能に応じて求められるべき交通性 能を確認し，道路を計画設計することができる. また, 予算, 空間, 環境といった制約条件の下で, 代替案を比 較検討することができ, 合理的な道路構造と交通運用の 組合せを選択することも可能である，その結果，従来よ りもコスト・パフォーマンスの高い道路の計画設計が可 能となる.

\section{(2) 今後の課題}

最後に, 本論文で構築した計画設計道路の交通性能 推計手法の推計精度を向上させるための課題を整理する.

\section{a) 事故や異常気象などの突発事象の影響}

図-6の観測值からも明らかなように, 事故や異常気象 (台風, 大雪など)など突発事象によって, 道路の交通性 能は大きく変化する. 今後は, 事故が発生しやすい交通 
状況・道路条件, 異常気象時における道路交通性能など を詳細に分析し，推計精度の向上を目指寸必要がある.

\section{b) BN交通容量の確率的変動}

最近の研究19223)244)どでは，BN交通容量は一定ではな く確率的に変動することが明らかにされている.このた め数多くのBNを対象に交通容量の変動特性を分析し, BN交通容量を一定值ではなく道路構造に応じて確率的 に変動させることで，より現実的な交通状況を想定する ことが望ましい.

\section{c) 道路条件の影響も考慮可能なq-V性能曲線}

地点固有の道路交通性能も推計できるよう, 道路の 横断面構成や線形などの影響を考慮できる $q$-v性能曲線 の定式化を行う必要がある. そのためには, テストコー スなどで走行実験を行ったり, 数は少ないものの道路構 造令の例外值の適用された地点で観測調查を行ったりす ることにより，分析データを収集することが必要である また，その際には安全性についても十分検証することが 重要である.

\section{d) 都市内幹線街路の $q-v$ 性能曲線}

走行性能が重視される都市内幹線街路では，信号制 御や沿道からの出入り, 路上駐停車車両などにより遅れ を被るため,ここで用いた地点速度ではなく区間の旅行 速度により走行性能を評価しなければならない.このた め, 信号制御パラメータ(オフセット, サイクル長など) や沿道アクセス挙動などが旅行速度に及ぼす影響を明ら かにし, 都市内幹線街路の旅行速度を推計する手法を構 築する必要があろう。

本論文は, 国土交通省道路局「道路政策の質の向上 に資する技術研究開発(課題名 : 道路機能に対応した性 能目標照査型道路計画・設計手法論の研究開発, 研究期 間 : H17〜H19年度, 研究代表者 : 中村英樹)」により実 施した内容の一部である.

謝辞 : 貴重なデータを提供していただいた，国土交通省 国土技術政策総合研究所，(株)高速道路総合技術研究所， ならびに(財)日本気象協会に深謝致します.

\section{参考文献}

1) 岡村 甫 : 良いものを安く造るシステムの実現に向 けて, 土木学会誌 第85 第4号, pp.3, 2000.4.

2) 大橋雄二 : 仕様規定から性能規定一 性能要求と保 証の歴史 法規制における性能規定化の趣旨と歴史 的位置付け, コンクリート工学, Vol.35, No11, pp.8-9, 1997.11.

3) 前川宏一 : 新しい示方書一仕様規定加性能照査一 - 改訂の動向・経緯, 土木学会誌 第85 第4号, pp.30-31, 2000.4.

4) (社) 日本道路協会: 道路構造令の解説と運用, 2004.

5) 中村英樹：道路交通パフォーマンスとサービ ス水準, 交通工学, Vol.40, No.1, pp.7-10, 2005.1.

6) 大口 敬, 中村英樹, 森田綽之, 桑原雅夫, 尾崎 晴男: ボトルネックベースで考える道路ネッ トワーク計画設計試論, 土木計画学研究・講演 集, vol.31, 4ページ, CD-ROM, 2005.6.

7) 中村英樹：道路機能に対応した性能照査型道 路計画と交通運用, IATSS Review, Vol.31, No.1, pp.75-80, 2006.

8) 中村英樹, 大口 敬, 森田綽之, 桑原雅夫, 尾崎晴 男 : 機能に対応した道路幾何構造設計のための道路 階層区分の試案, 土木計画学研究・講演集, vol.31, 4 ページ, CD-ROM, 2005.6.

9) 大口 敬, 中村英樹, 桑原雅夫 : 交通需要の時空間変 動を考慮した新たな道路ネットワーク計画設計試論, 土木計画学研究・講演集, vol.33, 4ページ, CD-ROM, 2006.6.

10）山田晴利, 中村英樹, 西川昌宏 : 交通量変動特性を 考慮した車線数決定方法に関する分析，土木技術資 料38-8, pp.26-31, 1996.8.

11) 中村英樹, 山田晴利: 日交通量変動パターンと道路 特性の分析, 土木計画学研究・講演集, No.16, pp. 2734, 1993.12.

12) 内海泰輔, 中村英樹 : 性能照査型道路計画設計のた めの道路の利用特性に応じたカテゴリ分類に関する 研究, 交通工学, Vol.42, No.5, pp.53-64, 2007.9.

13）内海泰輔, 中村英樹, 渡辺将光 : 性能照査型道路計 画設計のための年間を通じた時間交通需要変動推計 手法の構築, 土木計画学研究・論文集, Vol.24, pp.825-834, 2007.11.

14) 市川暢之, 渡辺二夫, 皆川聡一 : ドイツ・スウェー デンにおける道路構造と交通運用に関する調査報告, 高速道路と自動車, 第48巻 第10号, pp78-92, 2005.10

15) Lemke, $K$. : Temporäre Umnutzung von Seitenstreifen an Autobahnen, Straßenverkehrstechnik, pp.409-413, 2003.8.

16) Hong, S. and Oguchi, T.: Lane Use and Speed-Flow Relationship on Basic Segments of Multilane Motorways in Japan, 87th TRB Annual Meeting, 17 pages, CD-ROM, 2008.1 .

17) 越 正毅, 桑原雅夫, 赤羽弘和: 高速道路のトンネル, サグにおける潞滞現象に関する研究，土木学会論文 集, No.458/IV-18, pp.65-71, 1993.

18）岡村秀樹, 泉 正之: 都市間高速道路の交通容量と サービス交通量に関する考察，高速道路と自動車， 第45巻, 第12号, pp.26-35, 2002.12.

19）岡村秀樹, 渡辺修治, 泉 正之 : 高速道路単路部の交 
通容量に関する調查研究(下), 高速道路と自動車, 第 44巻 第3号, pp.30-40, 2001.3.

20) 日本道路協会 : 道路構造令の解説と運用, 1970.

21) 大口 敬 編著,(社)交通工学研究会：「交通沾滞」徹 底解剖, 丸善株式会社, 2005 .

22) Chung, E., Ohtani, O., Warita, H., Kuwahara, M., Morita, H. : Does Weather Affect Highway Capacity?, Proceedings of the 5th International Symposium on Highway Capacity and Quality of Service, Transportation Research Board, pp.139-146, 2006.7.
23) Jian Xing, 佐藤 久長, 高橋 秀喜, 吉川 良一: 高速 道路のボトルネック交通容量分布及び渋滞発生確率 の推定, 第26回交通工学研究発表会論文報告集, pp.49-52, 2006.10.

24) 稲野 晃, 中村英樹, 内海泰輔: ボトルネックが連 続する区間における渋滞現象の分析, 土木計画 学研究・講演集, vol.36, 4ページ, CD-ROM, 2007.11.

25) (社)交通工学研究会: 平成17年度道路交通センサス 一般交通量調査, 2007.

\section{時間交通需要変動特性を考慮した交通性能照査型道路計画設計法*}

内海泰輔**, 中村英樹 $* * *$

我が国の道路は，実現する交通性能を十分照査することなく過去に定められた仕様に基づき計画設計されて いる. 今まで以上にコスト・パフォーマンスの高い道路が求められる現在, 筆者らは仕様型ではなく性能照査 型の道路計画設計の必要性を提唱している. 本論文では, 時間交通需要の変動を考慮し計画設計道路の交通性 能を推計する手法を構築し，これを用いた性能照査型の道路計画設計法を提案した. これにより，その道路の 機能に応じて求められる性能を確認し道路を計画設計することができる．また予算，空間等の制約条件の下で， 代替案を比較検討することができ, 合理的な道路構造と交通運用の組合せを選択することも可能となる.

\section{A Methodology of a Traffic-Performance-Oriented Highway Planning and Design Considering Hourly Traffic Demand Fluctuation *}

By Taisuke UTSUMI** and Hideki NAKAMURA***

The existing highways in Japan are planned and designed based on the specifications determined in the past. However, economy and improvement of traffic-performance quality are demanded in the highways recently, and the authors have been advocating traffic-performance-oriented highway planning and design. In this paper, a methodology to estimate the traffic-performance of a planned inter-city highway throughout a year was established, and a traffic-performance-oriented highway planning and design methodology was proposed. This methodology provides several options of road crosssectional design for a planned highway, and makes it possible to adopt the most economical and best performing road structure and traffic operation option based on the latest knowledge. 